\title{
NATIONAL EDUCATION IDEOLOGY AS THE ORIENTATION OF THE SCHOOL CULTURE DEVELOPMENT POLICY AT SMA N 1 AND SMA N 3 YOGYAKARTA
}

${ }^{1)}$ Lusila Andriani Purwastuti, ${ }^{2}$ Sodiq A Kuntoro, ${ }^{3}$ Dwi Siswoyo

${ }^{1,3)}$ Fakultas Ilmu Pendidikan UNY, ${ }^{2)}$ Program Pascasarjana UNY lusila_ap@uny.ac.id,dwi_siswoyo@uny.ac.id

\begin{abstract}
This study aimed at describing the national education ideology as the orientation of the school culture development policy at SMA N 1 and SMAN 3 Yogyakarta. This research employed the qualitative approach through ethnography method. The subjects of the research were the school community. The object was the implementation of Pancasila on the development of the school culture. The data were collected through interviews, observations, and documentation. The data were analyzed using ethnography analysis as suggested by Spradley and they were validated by data triangulation and member checks. The results show that the national education ideology as the orientation of the school culture development is understood: (1) as an open ideology; (2) implemented on the basis value; instrumental values; the value of practices in the school culture; (3) The school culture in SMA N 1 and SMA N 3 is the implementation and contextualization of the values of Pancasila, along with the uniqueness of SMA N 1 with its "Teladan" icon which represents the religious morality and intellectual, as well as at SMA N 3 with its "Padmanaba" icon representing noble behavior. (4) Both schools have developed the school culture, namely: religious morality, social-culture, intellectual, and environment/management/leadership.
\end{abstract}

Keywords: Pancasila, Ideology, Education, Policy, School culture 


\section{INTRODUCTION}

Pancasila is the basis value and the ideology of Indonesia. Education is considered as one of the ways of life meaning that the ideology of the national education must be aligned to Pancasila as an ideology. It is stated in article 2 of the constitution no.20/2003 on the national education system saying that the national education must refer to Pancasila and the 1945 Constitution of The Republic of Indonesia (UUD '45) (Department of National Education, 2003). However, Pancasila as an educational ideology is still an abstract value. The national education ideology which refers to the philosophy of Indonesia, Pancasila, is clearly elaborated in the politics of education. Apart from the differences of the politics of educations, every country has to strongly admit that the sustainable development of the country depends on the quality of the people. Thus, the quality of the people as the das "Sollen" element of the development is strived through the education which principally refers to Pancasila as the educational ideology. Adams (1990) stated that from a deep analysis, an ideology can be an ultimate concept with greater understandings, more than other types of politics, including education.

The educational policy in Indonesia, after the reform in particular, tends to refer to foreign ideology. In this case, Tilaar (2009, p. 24) found some examples, namely: trend of corporatization of education in Indonesia such as: State-Owned Legal Agency (BHMN); the Constitution of the Republic of Indonesia (UU RI) No.17/2010 on the long term development planning 2005-2025; International Standard School (has been revoked by the Constitution Court); World Class University; Government Regulation No.22/2007 (Mulyadi, 2011). Meanwhile, Darmaningtyas (2013, p. 8) assumed that today's national education system is written on the Constitution No.20/2003 from the beginning of its formulation. This constitution causes controversy, especially dealing with its ideology. It seems that the soul of the national education is not in line with Pancasila gives bad impacts for the schools. The main issue stands on the interpretation of Pancasila which only understood in partial by certain parties.

This research is an empirical study on the Pancasila-based policy of the development of school cultures at SMA N 1 and SMA N 3 Yogyakarta. The study about Pancasila as an educational ideology is rarely conducted in this reform era. The ideology has not been being the main reference in the real life of Indonesian people. The main issue is how to put back Pancasila and UUD ' 45 as the soul of education (Darmaningtyas, 2013, p. 12). SMA N 1 and SMA N 3 Yogyakarta are both state schools where Pancasila is supposed to be the heart of the policy. The aim of this research was to explore the policy of school cultures at both schools and classify the policy of the development of school cultures there.

\section{RESEARCH METHOD}

This research is ethnography-qualitative which used qualitative design through ethnography method. It particularly emphasizes on the effort to explore the essence of the development of school cultures at SMA N 1 and SMA N 3 Yogyakarta without using hypotheses testing. This research was done in 1 year (March 2014-2015), 6 months conducted at SMA N 1 Yogyakarta and 6 months conducted at SMA N 3 Yogyakarta. Both schools are the state schools and popular in Yogyakarta.

The subjects of the research were all elements of SMA N 1 and SMA N 3 Yogyakarta. The informants were selected through snowball technique with the Vice Head of the school on community affairs as the key informant. The object of the research was the policy of the development of school cultures. The main instrument of the research was the researcher herself equipped by the audio and video recorder and field notes. The data gained through interviews, observations, and documentation. The data were analyzed using ethnographic analysis as suggested by Spradley (2007, pp. 129-143), following these steps: domain, taxonomy, components, and theme. In addition, the data were validated through triangulation and member checks.

\section{THE RESULTS AND DISCUSSION}

This research employed the analytical knife of Pancasila as the national ideology and the critical educational ideology in the discussion. Both analysis were used in order to gain a deep interpretation on the national 
education ideology as the orientation of the school culture development policy.

\section{The Interpretation of the School Elements on Pancasila as the Ideology of the National Education}

The results show that the school elements interpreted Pancasila as an open ideology. The concept of an open ideology means the basis values of Pancasila are implemented in the instrumental and practical values. The results of the implementation of those values at SMA N 1 and SMA N 3 Yogyakarta showed not much different results. The main difference can be seen from the 7 value systems implemented by SMA N 1 and the vision of SMA N 3 Yogyakarta. The formulation of the vision, mission, objectives, strategies from both schools are different but they have similarity in the essence and the implementation structure. Oetojo \& Alfian (1993) stated that Pancasila as an open ideology has three main values, namely: basis values (characterized as an abstract, general, and universal values), instrumental values (the tools to interpret the basis values), and practical values (used in the real life practice). Suseno (1994, pp. 366-367) argued that an open ideology does not set the target and the strategies of the development operationally. Yet they are mainly formulated in the form of objectives containing the values.

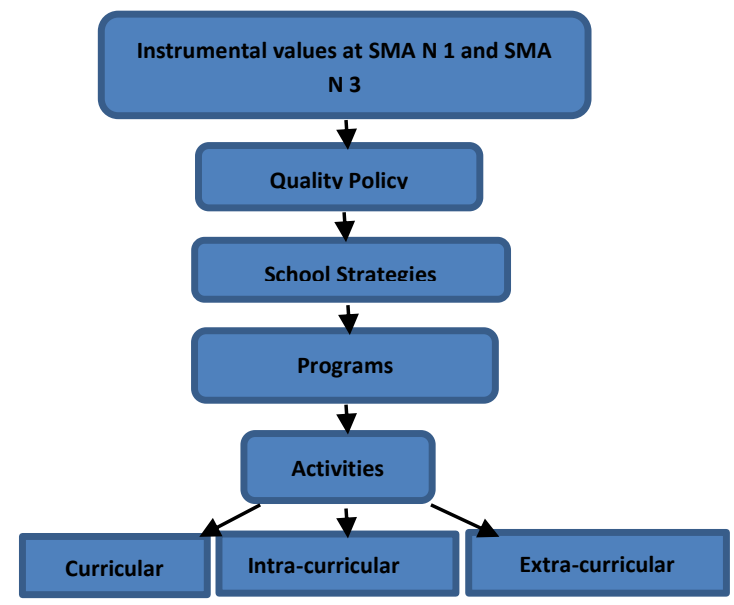

Figure 1. The implementation of the basis values of Pancasila into the instrumental values

Therefore, the objectives function as the critical reference to setting the targets, strategies, and means of the development in order to make it aligned with the noble values of the community. The result of the instrumental values can be seen in Figure 1 .

The implementation of the practical values can be found in the uniqueness of the school cultures of SMA N 1 and SMA N 3 Yogyakarta. SMA N 1 has an icon called "Teladan" and SMA N 3 has an icon named "Padmanaba" symbolized by a lotus. The implementation of the school culture can be seen in Figure 2.

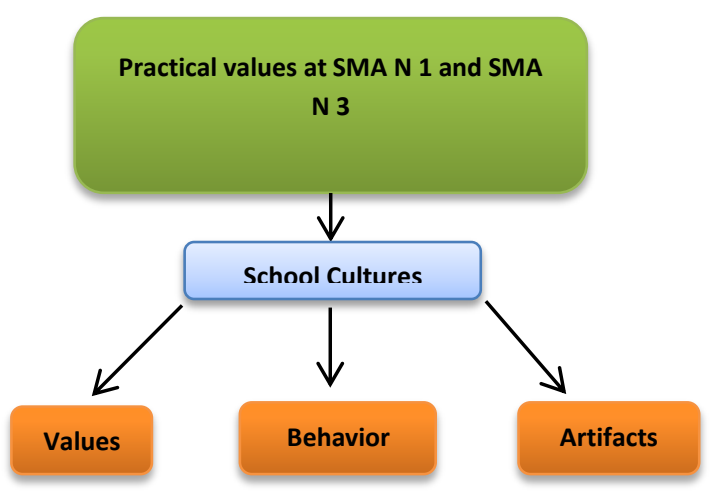

Figure 2. The implementation of practical values at school cultures.

The uniqueness of each school can be identified from the process of democratization. It already existed. Democratization is essentially a vision of the reformation. However, the process of democratization at the schools is still at the first stage. The schools have not interpreted Pancasila fully independently. Pancasila is merely interpreted for the sake of each school separately. It can be understood since the schools as the institutions where the national problems are sterilized from. In contrast, the schools are the right place to interpret the ideology of Pancasila openly and are the place for the young generation to be involved subjectively. Another evidence is because both schools are owned by the government which is really close to bureaucracy. Bureaucracy essentially uses structural approach that frequently is not matched with democracy values. This is aligned with the opinion of(Sastrapratedja (2013, p. 18) who stated that the fourth pilar of Pancasila describes democratic education. Democracy designates equality which implies that every person in Indonesia has the right to decide the policies related to their life.

Democracy is not a gift from God. It needs long time process to perfectly gain it. 
Reform era in Indonesia was a lesson of democracy and a milestone after being ruled under authoritative government. Habermas (Suseno, 2004, p. 19) stated that a complex structure of public spaces in Indonesia hides histories behind. Behind the wall, there were long and hard struggles such as: fights against colonialization, the founding the Republic of Indonesia, formulation of the 1945 Constitution, silent movements under New Order regime, human rights struggles, non-government organization movements, liberty for press, and other actions done by those who fights under the issues of human rights and constitution. Arendt (Suseno, 2004, p. 19) stated that the concept of power limits on the social mobilization among the people. A communicative power is formatted in the forms of public discussions, social movements, and law legalization of the House of People's Representative (DPR)/People's Consultative Assembly (MPR).

Theory of deliberation does not suggest revolution, but a country needs reformation to make the discourse movements of the public run in every level (social, poli-tical, and cultural). The movement increase the participation of the people. Therefore, there is no longer a gap between non-government organization activists, journalists, researchers, students, and politicians. A complex society and school society should directly or indirectly anticipate the pressure of capitalism and bureaucracy. Habermas (Suseno, 2004, p. 19) thought about Verrechtlichung, a legalization process to control the relationship among market, country, and society. Therefore those three elements do not over the limit. In this research school society is considered as a micro society, although from bureaucracy point of view, state schools are identified as government institutions. The school has two feet. One foot belongs to the state, and another one belongs to society. Thus, in one side state schools can be the representative of the government, while in the other side state schools represent the society. So state schools can mediate between govern-ment and society to reach an agreement.

The philosophy of politics suggested by Hebermas is an attempt to reconcile the concepts of Gesellschaft (society) and Gemeinscahft (community). Hebermas left a concept of individual a la liberalism in under- standing the practice of a law country as a discourse of each people. Hardiman (1993) explained that collectivistic models require a strong identification from individuals and their groups, which means the country. In fact, Indonesian people are considered as a complex society so they cannot be united merely by the idea of the good, meaning that the value for a certain culture or religion. It causes the requirement to identify the individuals and groups to become more democratic. Therefore in a complex society, the collectivistic models would be highly authoritative and disparage the individuals and antipluralism.

Pancasila as an open ideology of the national education is implemented and interpreted in the forms of constitutional regulations in Indonesia. The interpretation is basically still abstract and universal. Thus it is necessary to be contextualized according to the era. The Constitution of the National Education System No.20/2003 is one of the examples of the interpretation or implementation of Pancasila into the regulations adjusted to the era. Soeharto (2010, p. iii) argued that the foundation of education in Indonesia in the forms of values and ways of life can be empowered. It is also in line with the perspective of the educational ideology suggested by O'neil (2001, p. 42) which puts Pancasila in the category of a semi-liberal ideology, even though Pancasila is actually an open ideology and is potentially to be developed into a critical-religous educational ideology. However, this conceptualization needs whole power of the nation, especially academics. Basically, for Muhammadiyah organization, a Pancasila country is Dõr Al-'Ahdi Wa AlSyahõdah. From this Pimpinan Pusat Muhammadiyah perspective (2015, pp. 14-15), a Pancasila country is described as: dõr al'ahdi (a country with unity), dõr al-syahadah (a country to witness) and dar al-salam (a safe and wealthy country).

Siswoyo (2012) argued that Indonesian people must keep struggling to renovate, reconstruct, rejuvenate, and actualize Pancasila. The essential efforts to construct the philosophy of education can be done through: (1) vertical, meaning that the study about Pancasila is done by dialogues through deductivereflective-inductive ways to see the depth of the knowledge; (2) horizontal, meaning that 
the study of Pancasila is conducted through five cons, namely: continuity, convergent, concentric, contextual, and constructive; and (3) vertical-horizontal, meaning that the study is done using elective-incorporated-harmonious approach which can be implemented through dialectal-dynamic-anticipative-reflective-rejuvenated dialogues in critical ways to find out the fusion of the horizon that fits on the ideal philosophy of Pancasila. Sunarso (2011) also stated that the politics of education in the reform era was colored by the spirit of democracy so that the basis value of education is to make the democratic and responsible people of Indonesia.

Pancasila as an instrumental value system that consists of the basis value of God, humanism, unity, democracy, and justice actually has a chance to be a critical educational ideology. This ideology accommodates the independence, freedom of any kinds of domination and injustice, critical-creativeinnovative-explorative, and democratic. Education is a means of self awakening. The values of Pancasila principally are in one agreement with the values of critical educational ideology. Moreover, the essence of education is to freed human beings and to make people as independent people yet responsible to all dimensions of their life as mono-dualist/mono-pluralist (Notonagoro, 1987 , p. 3). The opportunity of Pancasila as critical ideology of education can be the orientation of the national policy for education because it is relevant to the context of education today. The purpose of education is to cover multiple intelligences comprehensively which include: intellectual intelligence, spiritual intelligence, emotional intelligence, and cultural intelligence. Meanwhile, the ideology of national education in Indonesia today is regarded as borrowing system from the other systems.

Deava (Sastrapratedja, 2013, p. 32) regarded that Indonesia has not absolutely decided the educational ideology, or even has no ability to develop its own ideology (Pancasila) into educational ideology. Many of policies of education in Indonesia have not stood at Pancasila values. As the result, the educational programs were run without the clear values of ideology, even ended tragically. The interpretation of Pancasila as an open ideology for educational purposes should be done all along with the spirit of today's era, namely: open, transparent, accountable, and democratic. In line with the opinion of Derrida, Pancasila as an ideology for the national education should be viewed as the narration that should be reinterpreted. It needs a specific method and logics. Sastrapratedja (2013) stated that it is necessary to use a new approach to find a new meaning, namely using humanistic approach which can be identified as follows: (1) emphasizing creativity, innovation, originality, and uniqueness; (2) finding meaning and values; (3) aiming at admiration; (4) aiming at rational and imaginative understanding; and (5) aiming at dramatic and emotional purposes. Moreover, how humanism works has these characteristics: (1) naturalistic-behavioristic; (2) historical realism; (3) existentialistic; (4) phenomenological; (5) existential phenomenological; (6) structuralism; (7) theory of system/holism/functionalism; (8) theory of critical social; and (9) theory of post-structuralism/post-modernism.

It seems that the implementation of the national education ideology on the school culture development policy at SMA N 1 and SMA N 3 Yogyakarta has indicated humanism with its characteristics, although there are still unfinished works to complete. It can be seen from some phenomena in the real life of the people which goes away from the values of Pancasila. Kuntoro (2013) argued that "the educational paradigm that should be strengthened is an education that develops the whole human being as an individual and social." This idea puts how to make people independent, creative, and responsible on the top of the priority.

Pancasila as a closed educational ideology is no longer relevant to be the main orientation and the way of life. It cannot be "reread" using an authoritarian approach which tends to use the weak scientific positivism/realism. None of big groups in Indonesia (such as religions, ethnics, political parties, and organizations) can be the one and only interpreter (of Pancasila) and then use their interpretation being applied for the whole country. Meanwhile, Pancasila as the national education open-ideology serves as: (1) a guidance of life, especially in educational life. Education cannot be run merely by doing technical-pragmatic actions without referring to the values of Pancasila; (2) a 
confirmation. It always put the mistakes occurring in educational practices on the right ideas of Pancasila values. The values of Pancasila become the judge of any deviation in education; (3) an integrator. The values of Pancasila are able to integrate the various opinions in life. Pancasila is the basis of unity in diversity.

The existence of diversity is admitted and respected, but there is still awareness of living as a nation. Driyarkara (2006, p. 209) stated that to live the world, the whole people have to be as one, and as one, the whole people live the world. There are two essential principles in finding out the meaning of Pancasila as an open ideology, namely: live the world and coexistence. It implies that Pancasila has no end of interpretation and has to be done all along by the component of the nation. There is no a single interpretation applied for the whole nation, even the government is none of the one and only interpreter.

\section{The Implementation of National Education Ideology in the Policy of Program and Activity Development at SMA Negeri 1 and SMA Negeri 3 Yogyakarta.}

The results of this study indicate that both schools (SMA Negeri 1 and SMA Negeri 3 Yogyakarta). The translation of Pancasila in School Culture Development Policy in Quality Policy. Quality Policy is used as reference or guidance in the preparation of School Strategic Plan. The school's strategic plan is spelled out in school programs and activities. All school policies, programs and activities are sourced or flow from the value system as a translation of Pancasila. The policy of developing the school culture as the translation of Pancasila values coherently begins by formulating the value system, vision, mission, and school goals. After that the School Quality Policy was made, then the school conducted a SWOT analysis and based on SWOT Analysis the school formulated an annual strategic plan. The annual Strategic Plan is outlined in School Program and Activities. The translation of Pancasila as culture development policy orientation in SMA Negeri 1 Yogyakarta and SMA Negeri 3 Yogyakarta the translation of Pancasila as an educational ideology in school culture development policy can be seen in Table 4 .

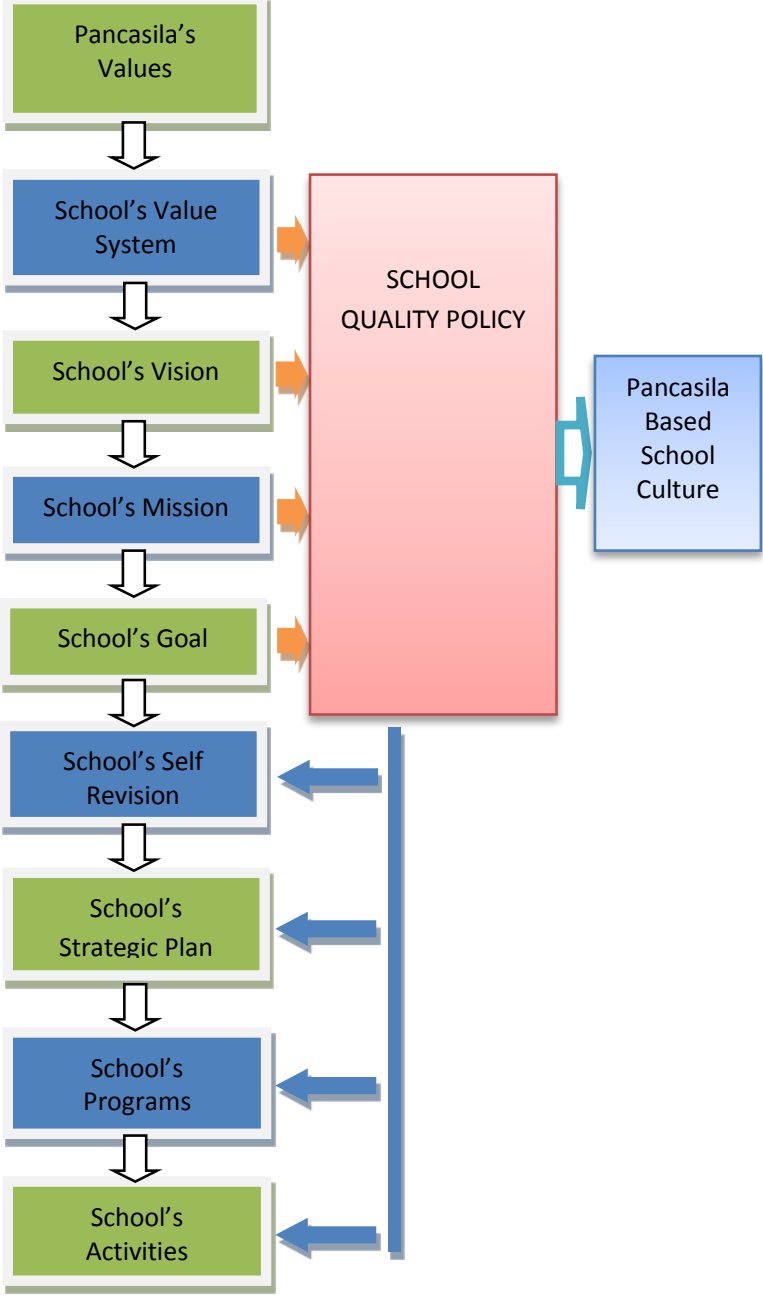

Figure 3. The Translation of Pancasila on the School Culture Development Policy

Pancasila as an open educational ideology has been elaborated in the school value system. The translation of Pancasila into a school culture development policy can be described as a description of the basic values to instrumental values, and to the Practice values.

Divinity, humanity, unity, democracy, and justice values are actually translated into or derived from instrumental values (values of tools) found in the school's quality policy and all school programs and activities also contain Practice values. As in the context of the state / nation ideology, Pancasila contains basic values that have universal abstract meaning, which is then described in instrumental value (UUD'45) which has a general collective meaning and lastly is described in Practice values in the form of specific public policies (eg, legislation on education). 


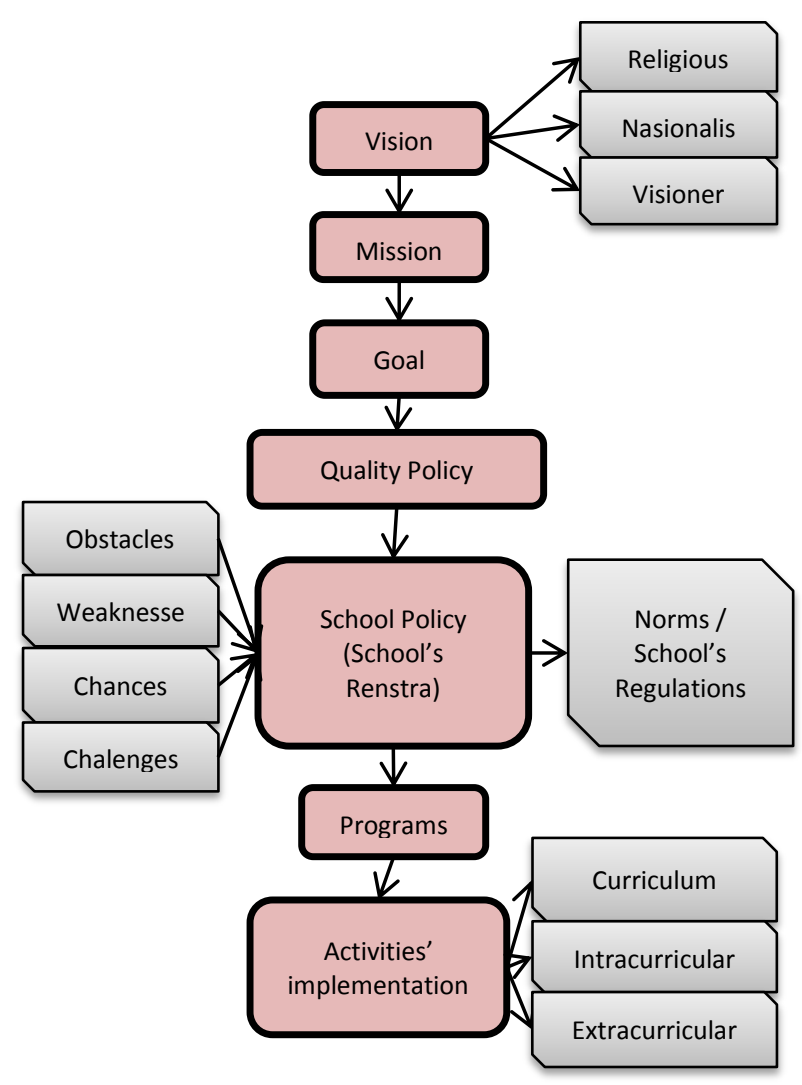

Figure 4. Instrumental Value in School Policy

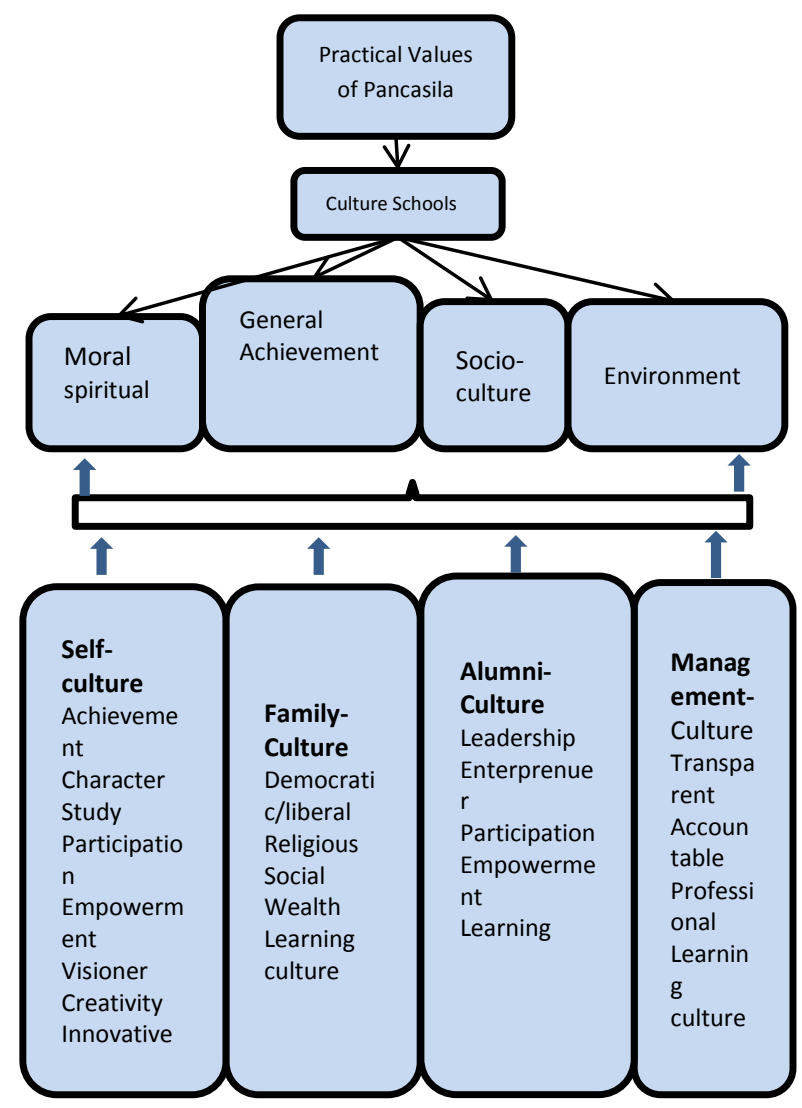

Figure 5. Practical Value of Pancasila in

School Culture Development Policy.
Pratte (1977, p. 16) states there are two criteria to test an ideology, namely the criteria of adequacy and confirmation. The adequacy criteria is associated with the value system that has a metaphysical, epistemological, and axiological basis. While the confirmation criteria are related to how the value system is applied in life. Do those values match with the reality. The confirmation criteriais related to the truth of the correspondence of an ideology.

As a positive norm law, Pancasila is defined in an explicit legislation. Pancasila becomes a source of value for the rule of law in Indonesia, as well as a source of moral norms for the implementation of law, state administration and nationality (Kaelan, 2013, p. 182). The embodiment of the 1945 Constitution is spelled out in national, regional and educational legislations.

The dedication of Pancasila into the School Values System is described randomly not in order to which in Pancasila. Pancasila as a unity of the value system is a comprehensive unity among its verses. This means that Pancasila can not be translated verse by verse. However, when Pancasila according to Notonagoro (1987, p. 10) is composed of a pyramidal hierarchy, the translation begins with the first verse. It is because the first verse embodied and covered the following verses (based on the logical law between the breadth of understanding and the scope of understanding is inversely proportional). The School value system described from Pancasila, puts the first verse on the fifth sequence with the formulation of intellectual, emotional, and spiritual balance. This suggests that the translation of the school's value system does not use logical thinking methods, but is based on the importance of the urgency of perceived value when the school's value system is formulated. Formulating a svhool value system based on quality, service, tomorrow shold be better than today, exemplary, transparency and accountability, coolness, togetherness, discipline, and sincerity. From the order of the seven value systems used by the school as the source, orientation and foundation of the school policy making, it can be seen that the fundamental values are placed in the last order. 
The translation of Pancasila into seven school value systems shows that the schools interpret Pancasila as an open educational ideology. The school has spelled out Pancasila values into contextual values matched with the school situation. Madjid (1999, p. 187) states that the interpretation and elaboration of the values of the principle of statehood and society in the Preamble to the 1945 Constitution should be left open to the dynamics of the development of society.

The values and sub values that exist in the school culture development policy are socialized, transmitted, transformed to individual private citizens of schools or schools as an organization that is dynamic, so it becomes a habit and eventually become the way of life of individual citizens of schools and school institutions. The trading of values is done through programs, activities, ceremonies, rituals, and living habits of school and school people as institutions. As this takes place continuously and passes from one generation to the next through a long history, there will be an iconization, self-identity, unique characteristics, local school wisdom, and an inherent brand image of society.

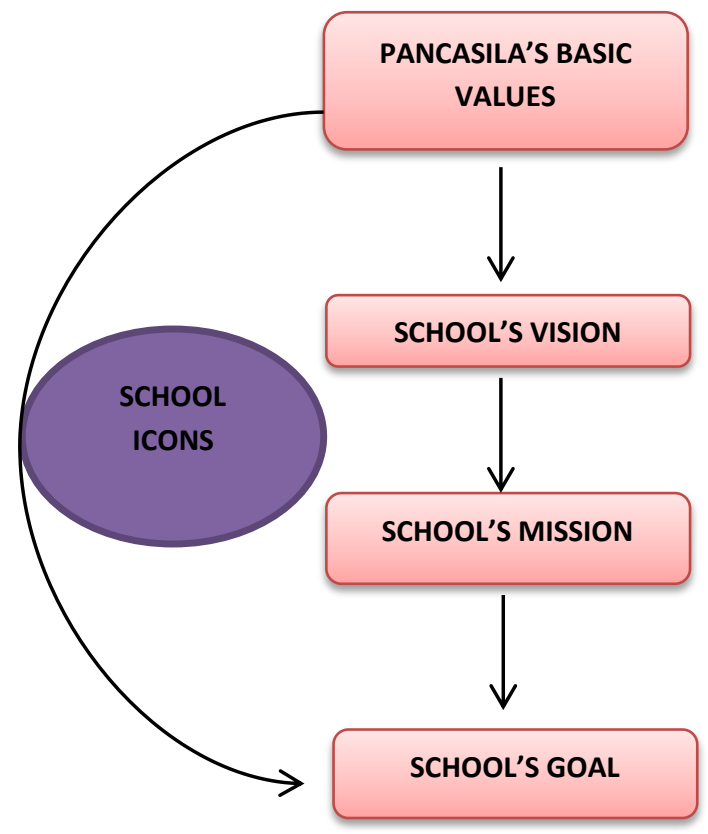

Figure 6. Connection of School Icons with Implementation of Pancasila Basic Values at School

School Cultural Development policy in its dynamics is always related to the dimensions of life outside school, which are po- litical (power), socio-cultural, and economic, even security aspects. Schools with Adibrata school culture are always used as model schools by the government. The government as a representation of power in this case the ministries and education offices will always choose schools with "superior culture" (Adibrata) as a model of its "strategic project". Adibrata school culture develops religious, social and cultural values that build a multi dimensional human being. Notonagoro refers to humans who are naturally monopluralist. The law of Sisdiknas no. 2 Year 1989 aims to develop a complete Indonesian man. While in Law no. 20. Year 2003 (Department of National Education, 2003) it is stated that the national education goal with long formulation which essentially describe Pancasila and Article 31 UUD'45. Conceptualization and its formulation in educational philosophy, educational ideology, educational politics, and educational Practice can be seen in the following Figure 7.

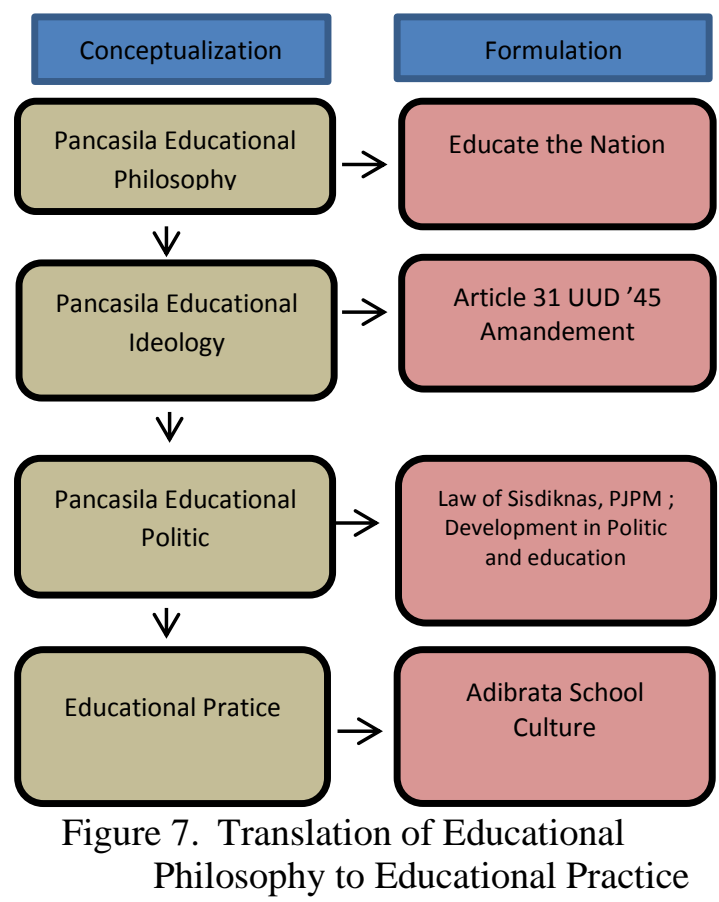

School culture development policies are always related to internal domains and external domains. The internal domain is the individual culture of every school member. The external culture is the culture of the community. In addition, external culture and internal culture together will form the culture of the organization. Schools as institutions / organizations must also have a culture. 


\section{CONCLUSIONS}

The conclusions that can be given in the research of National Education Ideology and Its Implementation on School Culture Development Policy are as follows:

Pancasila is interpreted as open ideology in 3 values namely: (1) the basic value, (2) the instrumental value, and (3) the value of Practice. SMA Negeri 1 Yogyakarta interpreted the basic values manifested in the school's seven values, vision, mission, and objectives. SMA Negeri 3 Yogyakarta is manifested in slogan, motto, and vision. The slogan is: "Bhakti Widya Ksatria Tama Tan Lelana Labet Tunggal Bangsa. Jaya-Jaya Padmanaba"; The instrumental value is manifested in norms, etiquette, school rules, quality policy, school's strategic plan; The Practice value is manifested in the school culture;

Interpretation of the school members about Pancasila as a national educational ideology is partial matched to the interests of the school. The policy on developing the school culture is outlined in the school's programs and activities that can be categorized into 4 types: (1) moral-religious; (2) sociocultural; (3) academic / intellectual, (4) environment /management /leadership;

School culture in SMA Negeri 1 Yogyakarta is a contextualization and transformation of Pancasila values. The dominant value contained in SMA Negeri 1 Yogyakarta is exemplary, the balance between intellectual, emotional, and spiritual. The prominent values such as discipline, order, regularity, obedience, legal-formal. The school culture of SMA Negeri 1 Yogyakarta is analogous to the scientific papers that follow the standard order. While the school culture in SMA Negeri 3 Yogyakarta is virtuous noble character. The dominant values in SMA Negeri 3 Yogyakarta are: noble, egalitarian, kinship, leadership, entrepreneurship, and cheerfulness. School culture in SMA Negeri 3 Yogyakarta is analogous to free essay writing which is full of expressions of independence. Both schools can be categorized as "Adi Brata" (positive and superior) schools.

\section{Suggestions}

For schools and colleges as the frontline of education open a dialogue, build networks and partnerships with various parties, create an inclusive school culture. College as an educational institution with college's tridarma has a big responsibility in the study of Pancasila academically. The results of its assessment and research can be disseminated and discussed with schools, government agencies, and the public in general. This suggestion is based on the results of the research that partnerships between alumni from colleges and new schools are limited to technical matters (funding, learning facilitators, event and activity speakers) and have not yet reached the academic studies related to the formulation of school culture based on Pancasila.

For schools that have not contextualized and transformed the values of Pancasila in their school culture, an alternative model which is a blend of school culture in SMA Negeri 1 and SMA Negeri 3 Yogyakarta as a model for the development of school culture can be considered, so that a superior school culture or "Adi Brata" can be realized. This suggestion is based on conceptualization findings of school culture development based on Pancasila.

\section{REFERENCES}

Adams, I. (1990). Kant, Pestalozzi and the role of ideology in educational thought. Journal of Philosophy of Education, 24(2), 257-269. https://doi.org/10.1111/j.14679752.1990.tb00238.x

Darmaningtyas. (2013). Pendidikan populis dari masa ke masa. In Seminar Nasional Dies Natalis ke-63 FIP UNY. Yogyakarta: Universitas Negeri Yogyakarta.

Department of National Education. UndangUndang Nomor 20 Tahun 2003 tentang Sistem Pendidikan Nasional (2003).

Driyarkara. (2006). Karya lengkap Driyarkara: esai-esai filsafat pemikir yang terlibat penuh dalam perjuangan bangsanya. Jakarta: Gramedia Pustaka Utama.

Hardiman, F. B. (1993). Menuju masyarakat komunikatif. Yogyakarta: Kanisius.

Kaelan. (2013). Negara kebangsaan pancasila. Yogyakarta: Paradigma. 
Kuntoro, S. A. (2013). Tantangan pendidikan dalam kehidupan modern: suatu perubahan paradigma. In Makalah dalam Pelepasan Guru Besar Purna tugas, April 2013. Yogyakarta: Universitas Negeri Yogyakarta.

Madjid, N. (1999). Cita-cita politik Islam. Jakarta: Paramadina.

Mulyadi, A. (2011, January 12). Ideologi dan pendidikan. Kompas. Retrieved from http://kompas.com/16/10/11

Notonagoro. (1987). Pancasila secara ilmiah populer. Jakarta: Pancuran Tujuh.

O'neil, W. F. (2001). Ideologi-ideologi pendidikan (Terjemahan Omi Intan Naomi). Yogyakarta: Pustaka Pelajar.

Oetojo, O. O., \& Alfian. (1993). Pancasila sebagai ideologi dalam berbagai bidang kehidupan bermasyarakat, berbangsa dan bernegara (2nd ed.). Surabaya: Karya Anda.

Pimpinan Pusat Muhammadiyah. (2015). Negara Pancasila sebagai Dâr Al-' Ahdi Wa Al-Syahadâh. Jakarta: Muhammadiyah.

Pratte, R. (1977). Ideology \& education. New York: David McKey Company.

Sastrapratedja. (2013). Lima gagasan yang dapat mengubah Indonesia. Jakarta: Pusat Kajian Filsafat dan Pancasila.
Siswoyo, D. (2012). Membangun konstruk filosofi pendidikan Pancasila. Ringkasan Disertasi Doktor, tidak dipublikasikan. Universitas Negeri Yogyakarta.

Soeharto, K. (2010). Politik pendidikan nasional: analisis ideologi pendidikan nasional interpretasi elite pendidikan Indonesia terhadap Undang-Undang Nomor 20 Tahun 2003 tentang Sistem Pendidikan Nasional. Disertasi, tidak dipublikasikan. Universitas Negeri Malang.

Spradley, J. P. (2007). Metode Etnografi, terj. Misbah Zulfa Elizabeth,. Yogyakarta: Tiara Wacana.

Sunarso. (2011). Dinamika pendidikan kewarganegaraan pada jenjang pendidikan dasar dan menengah (studi tentang politik pendidikan dan kurikulum orde lama, orde baru, dan era reformasi. Disertasi, tidak dipubilkasikan. Universitas Negeri Yogyakarta.

Suseno, F. M. (1994). Etika politik. Jakarta: Gramedia Pustaka Utama.

Suseno, F. M. (2004). Demokrasi deliberatif untuk Indonesia. Basis, 11-19.

Tilaar, H. A. R. (2009). Kekuasaan dan pendidikan. Jakarta: Rineka Cipta. 